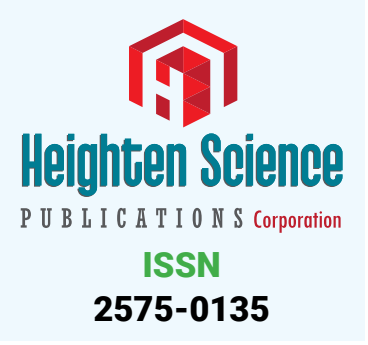

*Address for Correspondence: Sandro Rostelato Ferreira, Biological Sciences Course, Health Sciences Institute, Paulista University (UNIP), Sorocaba, SP, Brazil, Email:

sandrorostelato@yahoo.com.br

Submitted: 16 March 2018

Approved: 26 March 2018

Published: 27 March 2018

Copyright: @ 2018 Sanchez DME, et al. This is an open access article distributed under the Creative Commons Attribution License, which permits unrestricted use, distribution, and reproduction in any medium, provided the original work is properly cited.

Keywords: Cockroach; Fern; Insecticidal

\section{Pharmacological effects of Nephrolepis exaltata L. (fern) aqueous extract on an insect-based model (Nauphoeta cinerea)}

\author{
Danrley Mariel Egidio Sanchez ${ }^{1}$, Jocimar de Souza², Yoko \\ Oshima-Franco ${ }^{2}$ and Sandro Rostelato-Ferreira ${ }^{1 *}$ \\ 'Biological Sciences Course, Health Sciences Institute, Paulista University (UNIP), Sorocaba, \\ SP, Brazil \\ ${ }^{2}$ Post-Graduate Program in Pharmaceutical Sciences, University of Sorocaba (UNISO), \\ Sorocaba, SP, Brazil
}

\section{Abstract}

In this work we used semi-isolated heart of the cockroach Nauphoeta cinerea for the investigation of the pharmacological effects of extracts (aqueous, 1:1, 1:2, 1:4 and 1:8) from Nephrolepis exaltata L. leaves, a popular ornamental fern considered to be safe. The use of insects in experimental studies has grown due to the easy handling, proliferation/growing assuring its rapid obtention, and absence of ethical issues. An aqueous extract $0.2 \%$ was obtained after maceration of $1 \mathrm{~g} \mathrm{~N}$. exaltata leaves powder with $20 \mathrm{~mL}$ of distilled water (1:20). Diluted extracts in water were obtained to have the following proportion 1:1, 1:2, 1:4 and 1:8. Experiments $(n=4)$ consisted of $200 \mu \mathrm{L}$ addition onto semi-isolated heart preparation of $N$. cinerea with concomitant heart beating counting. Aqueous, 1:1 and 1:2 extracts paralyzed completely the heart beatings of cockroachs ( $p<0.05$ compared to saline control), but not $1: 4$ or $1: 8$, which showed only a slight decline ( $p>0.05$ compared to saline control). A preliminary thin layer chromatography showed the presence of unidentified terpenoid in aqueous extract of $N$. exaltata. These pharmacological findings of $N$. exaltata can be exploited for future use as insecticide or as dose-dependently cholinergic agent.

\section{Introduction}

The American fern Nephrolepis exaltata (L.) Schott known as 'Bostoniensis' is an ornamental plant considered to be safe [1], with few reports of contact dermatitis [24]. N. exaltata has ability to hydrolyze the acetates of phenols and aromatic-aliphatic alcohols in biotransformation reactions [5]. The plant also has been extensively studied in the metals adsortion, a process known as phytoremediation, such as arsenic [6], mercury [7], cadmium [8], and cuprum II [9]. Antimicrobial activity was reported using essential oil from aerial parts of $N$. exaltata which contain 2,4-Hexadien-1-ol (16.1\%), nonanal (14.4\%), $\beta$-Ionone (6.7\%) and thymol (2.7\%) [10].

The objectives of this work were: 1) to evaluate pharmacological effects of the aqueous extract of fern leaves from Nephrolepis exaltata on semi-isolated heart of cockroaches Nauphoeta cinerea, and 2) to find bioactive compounds in N. exaltata aqueous extract using thin layer chromatography. Our hypothesis was based on the influence of aqueous extract could have on cardiac beatings, since it is known that substances able in paralyzing the cardiac beatings could have insecticidal potential [11]. Research on cockroaches is becoming frequent by its easy maintenance, low cost, rapid reproduction and there are no restrictions on its use [12]. Besides, in recent years, 
organic agriculture has become an alternative to food consumption, since the problems that insecticides can cause to human health and the environment are already known [13]. However, the extract from Nephrolepis exaltata tested here showed a cardiotoxic effect, with a possible effect induced by a terpene, could be used as an insecticide.

\section{Material and Methods}

\section{Botanical material}

The botanical material was commercially purchased from Companhia de Entrepostos e Armazéns Gerais de São Paulo (CEAGESP), in Sorocaba city, cleaned and weight (6.4 g), oven- air dried during $24 \mathrm{~h}$ at $40^{\circ} \mathrm{C}$, and further milled to obtain $1.11 \mathrm{~g}$ of powder (percentage of incoming=17.15\%).

\section{Extracts obtention}

The extract was obtained by water maceration method [14]. For each $1 \mathrm{~g}$ plant powder was used $20 \mathrm{~mL}$ distilled water, put in contact during $48 \mathrm{~h}$, resulting in a $0.2 \%$ aqueous extract. Dilutions of aqueous extract in water were also performed to have $1: 1,1: 2,1: 4$ and $1: 8$ extracts.

\section{Biological material}

Cockroaches (Nauphoeta cinerea) commercially purchased from Pet Shop Bicho \& Cia, Sorocaba city, were put in an adequate recipient for its creation. The cockroaches had water and food (as fruits and vegetables) ad libitum.

\section{Semi-isolated heart of Nauphoeta cinerea preparation}

The cockroaches were immobilized using entomological pinheads. The lateral margins of abdomen were cut along on each side [15] and the cuticle removed using an ophtalmic scissor to expose the visceral organs which were carefully keep out using a tweezer, in order to view the vascular system. After, the insect was put under a 30X magnifying glass (Carl Zeiss, Germany) aiming to visualize the cardiac beatings. The mean beatings/minute in the first 5 minutes were considered as zero time. After the extract addition $(200 \mu \mathrm{L}$ of each), the beatings were accounted in intervals of 5,15 , and 30 minutes [16]. Experimental groups $(n=4)$ were randomly distributed in: saline control, pure extract, extract diluted in water 1:1, 1:2, 1:4 and 1:8. The obtained results were compared to pharmacological controls as acetylcholine chloride $(110 \mu \mathrm{M}$, MW 181.66, Sigma-Aldrich) and adrenaline (110 $\mu \mathrm{M}$, MW 183.20, Sigma-Aldrich), at the same $200 \mu \mathrm{L}$.

\section{Thin layer chromatography (TLC)}

Aliquots of pure extract from the powder of $N$. exaltata were spotted onto $0.3 \mathrm{~mm}$ thick silica-gel or GF254 plates (Merck ${ }^{\circledR}$ ) along with appropriate standards [17, 18]. The presence of phytochemical groups such as phenolic acids and flavonoids was investigated by comparison with the following standards (Sigma): caffeic acid, chlorogenic acid, tannic acid, rutin, quercetin, atropin, $\beta$-sitosterol, cumarin, lupeol, betulin, oleanolic acid, ursolic acid, all solubilized in absolute ethanol $(1 \mathrm{mg} / \mathrm{mL})$. Spots were observed with or without chromogenic agent (UV light, $360 \mathrm{~nm}$ ). The spot of each standard was compared with spots exhibited by N. exaltata extract. The following systems were used as described elsewhere [19]: System I: ethyl acetate (Synth ${ }^{\circledR}$ ); formic acid (Anidrol ${ }^{\circledR}$ ); acetic acid $\left(\mathrm{Chemco}^{\circledR}\right) ; \mathrm{H}_{2} \mathrm{O}(100: 11: 11: 24)$. System II: ether (Anidrol ${ }^{\circledR}$ ); toluene $\left(\right.$ Synth $\left.^{\circledR}\right)$ (1:1). Chromogenic agentes were: A) NP/PEG: 5\% (v/v) ethanolic NP (diphenylboric acid 2-aminoethyl ester, Sigma ${ }^{\circledR}$ ), followed by $5 \%(v / v)$ ethanolic PEG4000 (polyethylene glycol 4000, Synth ${ }^{\circledR}$ ), being visualized under UV light at $360 \mathrm{~nm}$. B) Sulphuric anisaldehyde $(0.5 \mathrm{~mL}$ anisaldehyde solved in $10 \mathrm{~mL}$ acetic acid, $85 \mathrm{~mL}$ methanol and $5 \mathrm{~mL} \mathrm{H}_{2} \mathrm{SO}_{4}$ concentrate), heating the plaque during $10 \mathrm{~min}$ at 100 ${ }^{\circ} \mathrm{C}$. C) Dragendorf/KOH reagent: Dragendorf (Solution "a"-2 g bismut subnitrate in 25 
$\mathrm{mL}$ acetic acid, complete to $100 \mathrm{~mL}$ distilled water. Solution "b" -40 g KI, complete to $100 \mathrm{~mL}$ distilled water. Mixture $10 \mathrm{~mL}$ solution "a" and $10 \mathrm{~mL}$ solution "b", add $20 \mathrm{~mL}$ acetic acid, complete to $100 \mathrm{~mL}$ distilled water); $\mathrm{KOH} 10 \%$ diluted in ethanol.

\section{Statistical analysis}

Results were expressed as the mean \pm standard error mean $( \pm$ SEM). The Student's $t$-test or repeated measures ANOVA were used for statistical comparison of the data. The significance level was set at $5 \%$.

\section{Results and Discussion}

Figure 1 expresses the percentage of heart beating (Y-axis) in function of counting in intervals of 5, 15 and 30 minutes (X-axis) of classic pharmacological drugs as adrenaline and acetylcholine in comparison to saline. Notice the effects sympathomimetic (increase of heart beatings) and parasympathomimetic (decrease of heart beatings) in semi-isolated heart of $N$. cinerea, induced by adrenaline and acetylcholine, respectively. Adrenaline is the active sympathomimetic hormone from the adrenal medulla. It stimulates both the alpha- and beta- adrenergic systems, consequently stimulates the heart [20]. Acetylcholine is a neurotransmitter found at neuromuscular junctions, autonomic ganglia, parasympathetic effector junctions, a subset of sympathetic effector junctions, and at many sites in the central nervous system 21]. At heart, acetylcholine acts causing bradycardia due to blockade of postjunctional muscarinic receptors, whereas the slight recovery seen at 15 and 30 minutes can express the vagal stimulation [22].

Figure 2 shows the pharmacological effects of extracts in different concentrations. The heart beating blocker effect seen with aqueous and diluted 1:1 and 1:2 extracts can be exploited for insecticidal use of the fern $N$. exaltata, which is among the most popular ornamental ferns [23].

Diluted 1:4 N. exaltata extract did exhibit similar profile of acetylcholine, which means that the blocker effect is a dose-dependent pharmacological event. On the other words, other than insecticidal use can be ventured to $N$. exaltata, for example, as a cholinergic agonist. However, the future pharmacodynamic of $N$. exaltata must be studied.

Figure 3 shows the chromatographical profile of $N$. exaltata aqueous extract face to two systems of mobile phases and three chromogenic agents, which matched to each other, resulted in the phytogroup identification. Note that N. exaltata exhibits the same chromatographical profile of terpenes (Figure 3A, 3B) but does not as flavonoids (Figure 3E).

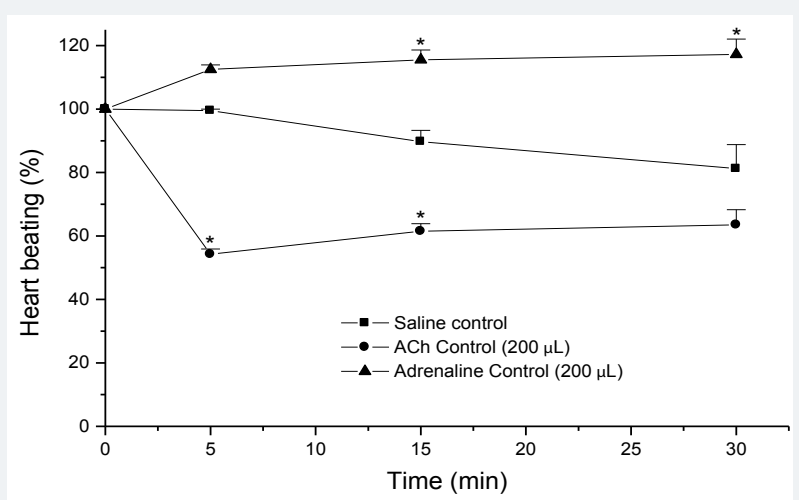

Figure 1: Semi-isolated heart preparation of Nauphoeta cinerea. Pharmacological effects of $200 \mu \mathrm{L}$ addition of adrenaline and acetylcholine (both $110 \mu \mathrm{M}, \mathrm{n}=4$ ), in comparison to SALINE CONTROL ( $n=4$ ), on the exposed preparation, with sympatho- and parasympatho- mimetic effects, respectively. ${ }^{\star} p<0.05$ compared with saline control. 


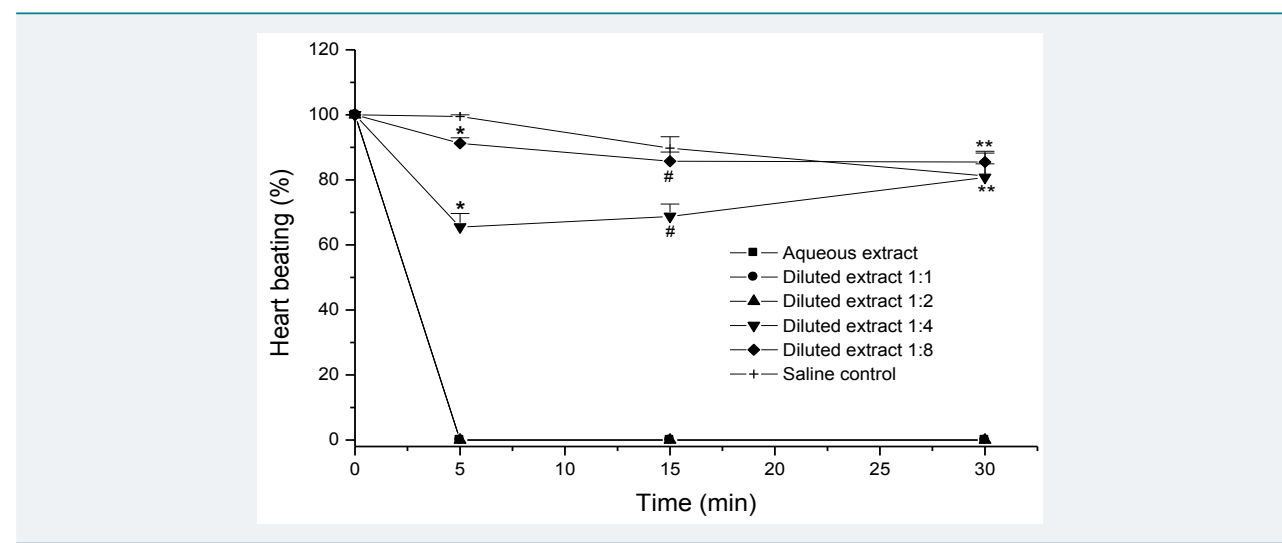

Figure 2: Semi-isolated heart preparation of Nauphoeta cinerea. Pharmacological effects of $200 \mu \mathrm{L}$ addition of Nephrolepis exaltata aqueous extracts $(n=4$, each), in comparison to saline control $(n=4)$. Note the irreversible blockade of heart beating with aqueous and diluted 1:1 and 1:2 extracts. Diluted 1:4 and 1:8 extracts showed declines of $35 \%$ and $9 \%$, respectively at first 5 minutes, with subsequent recovery at 30 min with no statistical difference in comparison to saline control. ${ }^{*} p<0.05$, in comparison among groups and saline control. \#p $>0.05$ (in 1:4 extract, compared to acetylcholine; 1:8 extract, compared to saline control). ${ }^{\star \star} p>0.05$ compared to saline control.

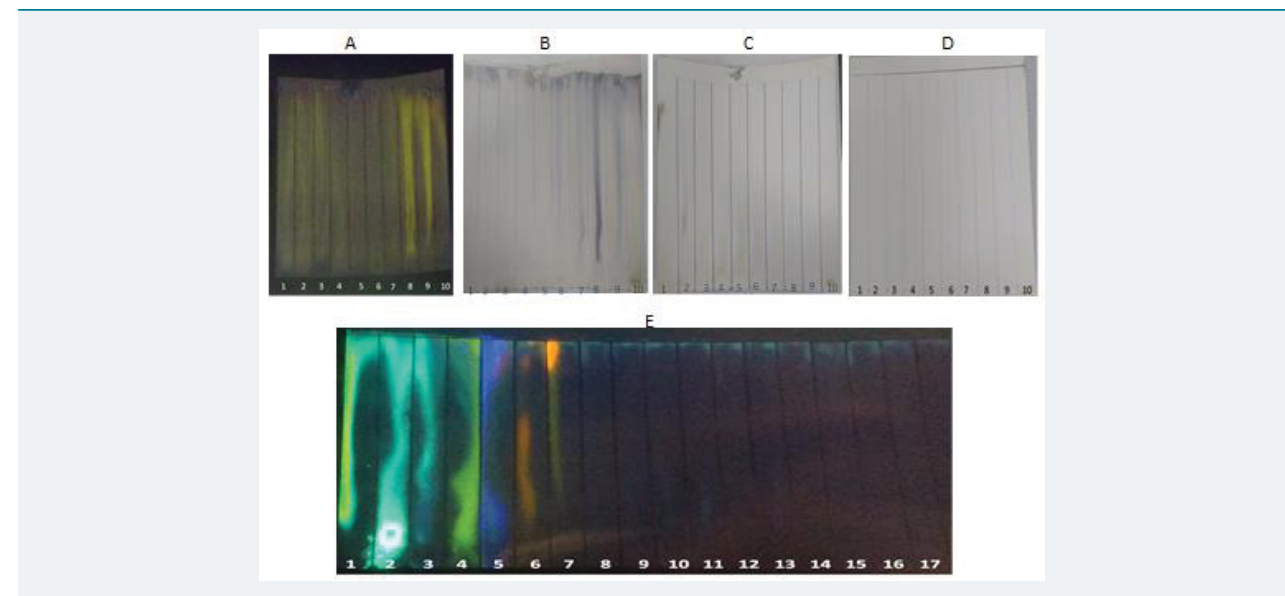

Figure 3: Thin layer chromatography - System I (A, B, C, and E). System II: D. Chromogenic agents: Sulphuric anisaldehyde: A (under $360 \mathrm{~nm}$ UV light) and B (with no UV light). Dragendorf/KOH 10\%: C. NP/PEG: D and E. Standars of A, B, C, and D: 1, Atropine. 2, $\beta$-Sitosterol. 3, Cumarin. 4, Lupeol. 5, Betulin. 6 and 7. Oleanolic acid. 8 and 9. Ursolic acid. 10. Nephrolepis exaltata aqueous extract. Standards of E: 1, Caffeic acid. 2, Chlorogenic acid. 3 Tannic acid. 4, Apigenin. 5, Gallic acid. 6, Rutin. 7, Quercetin. 8, Atropine. 9, $\beta$-Sitosterol. 10, Cumarin. 11, Lupeol. 12, Betulin. 13 and 14, oleanolic acid. 15 and 16. Ursolic acid. 17. Nephrolepis exaltata aqueous extract.

Terpenes are a diverse group of more than 30,000 lipid-soluble compounds. Terpenoids are classified according to the number of isoprene units they contain. Thus, 1 unit, hemiterpene; 2 units, monoterpenes; 3 units, sesquiterpenes; 4 units, diterpenes; 5 units, sesterpenes; 6 units, triterpenes; and 8 units, tetraterpenes [24]. Terpenes exhibit a range of toxicity which confer antimicrobial properties and a wide range of effects within the insect central nervous system, but very low toxicity to mammals [25]. Phytochemical studies must be carried out in order to identify the terpene structure in aqueous extract of $N$. exaltata.

\section{Conclusion}

Concluding, aqueous extract of fern Nephrolepis exaltata is cardiotoxic to cokroaches Nauphoeta cinerea on a dose-dependent manner. An unidentified terpene present in $N$. exaltata could contribute to this effect.

\section{References}

1. Der Marderosian A, Giller F, Roia FJr. Phytochemical and toxicological screening of household plants potentially toxic to humans. Journal of Toxicology and Environmental Health. 1976; 1: 939-953. Ref.: https://goo.gl/uiHKdT 
2. Geller-Bernstein CC, Keynan N, Bejerano A, Shomer-Ilan A, Waisel Y. Positive skin tests to fern spore extracts in atopic patients. Annals of Allergy. 1987; 58: 125-127. Ref.: https://goo.gl/BT2Stb

3. Stoof TJ, Bruynzeel DP. Contact allergy to Nephrolepis ferns. Contact Dermatitis. 1989; 20: 234-235. Ref.: https://goo.gl/kFmXZU

4. Andersen F, Paulsen E. Allergic contact dermatitis caused by the Boston fern Nephrolepis exaltata 'Bostoniensis'. Contact Dermatitis. 2016; 75: 255-256. Ref.: https://goo.gl/QoCEDy

5. Mironowicz A, Kromer K, Pawlowicz P, Siewinski A. Abilities of some higher plants to hydrolyze the acetates of phenols and aromatic-aliphatic alcohols. Acta Societatis Botanicorum Poloniae. 1994; 63: 43-48. Ref.: https://goo.gl/n9v7JS

6. Tu S, Ma L, Luongo T. Root exudates and arsenic accumulation in arsenic hyperaccumulating Pteris vittata and non-hyperaccumulatting Nephrolepis exaltata. Plant Soil. 2004; 258: 9-19. Ref.: https://goo.gl/CBajgA

7. Chen J, Shiyab S, Han FX, Monts DL, Waggoner CA, et al. Bioaccumulation and physiological effects of mercury in Pteris vittata and Nephrolepis exaltata. Ecotoxicology. 2009; 18: 110-121. Ref.: https://goo.gl/SD8WVc

8. Samarakkody R, Chathuranga D, Perera I, Fonseka DLCK, Iqbal MCM. Removal of cadmium (II) from contaminated soil by Nephrolepis exaltata. Conference: Interhational Symposium on Agriculture and Environment. 2014.

9. Rao RAK, Khan U. Adsorption studies of Cu (II) on Boston fern (Nephrolepis exaltata Schott cv. Bostoniensis) leaves. Applied Water Science. 2017; 7: 2051-2061. Ref.: https://goo.gl/7cuLXb

10. El-Tantawy ME, Shams MM, Affi MS. Chemical composition and biological evaluation of the volatile constituents from the aerial parts of Nephrolepis exaltata (L.) and Nephrolepis cordifolia (L.) C. Presl grown in Egypt. Natural Product Research. 2016; 30: 1197-1201. Ref.: https://goo.gl/7LUVmb

11. Edwards JS. The action and compostion of the saliva of an assassin bug Platymeris rhadamanthus Gaerst (Hemiptera, Reduviidae). Journal of Experimental Biology. 1961; 38: 61-77. Ref.: https://goo.gl/kRhC8y

12. Rodrigues NR, Nunes ME, Silva DG, Zemolin AP, Meinerz DF, et al. Is the lobster cockroach Nauphoeta cinerea a valuable model for evaluating mercury induced oxidative stress? Chemosphere. 2013; 92 1177-1182. Ref.: https://goo.gl/yYDtVQ

13. Nicolopoulou-Stamati P, Maipas S, Kotampasi C, Stamatis P, Hens L. Chemical Pesticides and Human Health: The Urgent Need for a New Concept in Agriculture. Front Public Health. 2016; 4: 148. Ref.: https://goo.gl/mnw2J9

14. Farmacopéia Brasileira. $4^{a}$ edição. São Paulo: Editora Atheneu. 1988.

15. Rodrigues V, Dörr FA, Morbi B, Pinto E, Dal Belo CA, et al. Effects of a cyanobacterial extract containing-anatoxin-a(s) um the cardiac rhythm of Leurolestes circunvagans. Brazilian Journal of Pharmacognosy. 2012; 22: 775-781. Ref.: https://goo.gl/R6a4iD

16. Barreto YC, Leal AP, Oliveira RS, Vinadé L, Santos TG, Dal Belo CA. Atividade neurotóxica do veneno de Rhinella ictérica (Spix, 1824) em baratas da espécie Nauphoeta cinerea. In: Anais do Salão Internacional de Ensino, Pesquisa e Extensão (SIEPE): 2016; Rio Grande do Sul. Rio Grande do Sul, RS: Universidade Federal do Pampa. 2016; 8. Ref.: https://goo.gl/GhjJR1

17. Harbone JB. Phytochemical Methods: A Guide to Modern Techniques of Plants Analysis. Chapman \& Hall, London, England, 3rd Edition. 1998.

18. Simões CMO, Schenkel EP, Gosmann G, Mello JCP, Mentz LA and Petrovick PR. Farmacognosia: da Planta ao Medicamento. UFRGS/UFSC, Porto Alegre/Florianópolis, Brazil, 5th Edition. 2004.

19. Costa, KN, Gomes RM, Farrapo NM, Franco YO. Validação Farmacológica de Fitoqúimicos Comerciais sob o Parâmetro da Junção Neuromuscular (JNM) e do Perfil Cromatográfico. In: Oliveira JM Gerenutti M, Miranda RC, Franco YO, Franzoni V. Os Múltiplos Olhares da Pesquisa: da observação ao conhecimento (pp. 13-29). Sorocaba: Eduniso 2011.

20. MeSH, Adrenaline. Ref.: https://goo.gl/mjRwvk

21. MeSH, Acetylcholine. Ref.: https://goo.gl/9w22VS

22. Fryer AD, Maclagan J. Ipratropium bromide potentiates bronchoconstriction induced by vagal nerve stimulation in the guinea-pig. European Journal of Pharmacolgy. 1987; 139: 187-191. Ref.: https://goo.gl/3mE39W 
23. Hennequin S, Hovenkamp P, Christenhusz M, Schneider H. Phylogenetics and biogeography of Nephrolepis -a tale of old settlers and young tramps. Botanical Journal of the Linnean Society. 2010; 164: 113-127. Ref.: https://goo.gl/6wkaDb

24. Kennedy DO, Wightman EL. Herbal extracts and phytochemicals: plant secondary metabolites and the enhancement of human brain function. Advances in Nutrition. 2011; 2: 32-50. Ref.: https://goo.gl/LypRwq

25. Rattan RS. Mechanism of action of insecticidal secondary metabolites of plant origin. Crop Protection. 2010; 29: 913-920. Ref.: https://goo.gl/hwC6ez 